\title{
Rethinking the Quality Culture of Indonesian Madrasa in the Global Era
}

\author{
Mohammad 'Ulyan ${ }^{1 *}$, Guntur Dwi Purwanto' ${ }^{2}$, Abdul Basit ${ }^{3}$ \\ ${ }^{1}$ Institut Agama Islam Negeri Purwokerto, ${ }^{1}$ Institut Teknologi Telkom Purwokerto \\ ${ }^{2}$ Institut Agama Islam Negeri Purwokerto, ${ }^{3}$ Institut Agama Islam Negeri \\ Purwokerto
}

*Corespending author: ${ }^{1 *}$ ulyan@ittelkom-pwt.ac.id, ${ }^{2} 201771018 @ m b s$. iainpurwokerto.ac.id, ${ }^{3}$ abdulbasit1969@gmail.com

Article
History:

Submit:

2020-10-13

Publish:

2021-05-11

\section{Abstract}

Madrasa have a big role in building the Indonesian nation. The challenges of education in the era of globalization are getting bigger. However, many madrasa do not have the quality according to the standard. Therefore it is necessary to rethink the quality culture of madrasa in the global era. This type of research is qualitative research and includes field research. Data analysis using Miles and Huberman analysis techniques that include data reduction, display data, and conclusion drawing/ verification. The results of research conducted by the author on the implementation of quality culture madrasa in MTs Ma'arif NU 4 Kemranjen can be concluded that wujud from the quality culture madrasa (religious culture) in MTs Ma'arif NU 4 Kemranjen as a form of development of pai subject family in accordance with the theory that includes; (1) mushofahah (2) memorization juz 'amma (3) istighasah and prayer together (4) dhuha prayer (5) friday box running (6) congregational dhuhur prayer (7) religious message. While what is not contained in the theory is (1) PHBI (2) reading asmaul husna (3) the use of polite uniforms and covering the aurat (4) pesantren kilat (5) reading yasin and tahlil (6) extra-curricular religious (7) religious tests (8) halal bihalal. The implementation uses a persuasive strategy that emphasizes on accuracy and habituation.

Keywords: Indonesian Madrasa; Quality Cultur; Global Era 
Journal Homepage http://ijssr.net/index.php/ijssr

This is an Open Access article under the CC BY SA license

https://creativecommons.org/licenses/by-sa/4.0/

Published by Indonesian Academy of Social and Religious Research

\section{Introduction}

The term 'madrasa' comes from the Arabic language which is rooted in the word darasa which has the meaning of 'learning'. According to the original language, madrasa refers to all types of schools, be it Islamic schools or public schools. In areas of Asia that do not speak Arabic, madrasa have a narrowing of meaning that is to schools that teach about Islamiceducation. In Indonesia, the word madrasa refers to religious schools with classes and curriculum that mostly cover $70 \%$ of general subjects and $30 \%$ of religious subjects. ${ }^{2}$ Data on the number of madrasa students in Indonesia in 2021 as many as 10,007,450 students, 82,128 institutions from RA to MA. ${ }^{3}$

The main purpose of madrasa is to produce graduates like those from public schools, but with a better understanding of Islam. ${ }^{4}$ Madrasa in Indonesia was born from education in mosques, surau and pesantren. Although in subsequent developments, madrasa are not always emphasized on these three things. There are two factors that contribute to the growth of madrasa in Indonesia, namely the response to the political policies of the Dutch colonial government and the emergence of a reform movement by Muslim intellectuals. ${ }^{5}$

Before Indonesia became independent, Madrasa was established independently by individuals and religious organizations. Meanwhile, after

1 Mukhlis Abu Bakar, Rethinking Madrasa Education in a Globalised World, ed. Mukhlis Abu Bakar, Rethinking Madrasa Education in a Globalised World, 1st ed. (New York,: Routledge, 2018), https://doi. org/10.4324/9781315184234.

2 Martin van Bruinessen, "Traditionalist and Islamist Pesantrens in Contemporary Indonesia," in The Madrasa in Asia, ed. Annelies Moors, Mathijs Pelkmans, and Abdulkader Tayob (Amsterdam: Amsterdam University Press, 2008), 222, https://doi.org/10.1017/9789048501380.009.

3 Kementerian Agama Republik, "REKAPITULASI DATA POKOK PENDIDIKAN ISLAM," EMIS, 2021, http://emispendis.kemenag.go.id/dashboard/.

4 Noorhaidi Hasan, "The Salafi Madrasas of Indonesia Chapter Author(s): Noorhaidi Hasan Book Title: The Madrasa in Asia Book Subtitle: Political Activism and Transnational Linkages," in The Madrasa in Asia: Political Activism and Transnational Linkages, ed. Annelies Moors, Mathijs Pelkmans, and Abdulkader Tayob (Amsterdam: Amsterdam University Press, 2008), 247.

5 Supani Supani, "Sejarah Perkembangan Madrasa Di Indonesia," INSANIA : Jurnal Pemikiran Alternatif Kependidikan 14, no. 3 (2009): 1-14, https://doi.org/10.24090/insania.v14i3.376. 
Indonesia's independence, especially since the establishment of the Ministry of Religious Affairs, efforts to develop madrasa continue to be carried out by the government. Among the policies that have been taken are the Joint Decree / SKB of three Ministers, the Minister's Decree, the 1984 Curriculum, the Special Program of Madrasa Aliyah or Madrasa Aliyah Keagamaan, the 1994 Curriculum, and the Flagship Madrasa. The regulation shows that the government supports the development of madrasa in Indonesia. ${ }^{6}$

This is in line with Syarif's research which states that the growth of madrasa history in Indonesia there are two momentums that determine the existence of Madrasa. First, SKB 3 ministers in 1975 which became the entrance of madrasa recognition as an Islamic educational institution equivalent to a public school. Second, the National Education System Law no. 2/1989 makes madrasa not only as educational institutions equivalent to public schools, more than that madrasa are educational institutions or public institutions that are Islamic.

Ronald's paper concludes that madrasa and pesantren as a form of Islamic education in Indonesia have a desire to modernize and meet the modern needs of students and society while maintaining strong roots in traditional Islamic education. This is important for the contribution to Indonesia's future as a plural, peaceful, and democratic society. ${ }^{8}$ Background integration of schools and madrasa into pesantren among others eliminate the image of pesatren which was originally as a traditional educational institution and not quality, is now a quality educational institution. ${ }^{9}$

Takdir dissertation concludes local wisdom as a value system in educational activities including in the school management process is able to form positive school performance so as to create a quality climate oriented towards the establishment of a school quality culture. ${ }^{10}$

6 Ahmad Syar'i, A. Akrim, and Hamdanah, "The Development of Madrasa Education in Indonesia,” Revista Argentina de Clinica Psicológica XXIX, no. 4 (2020): 513-23, https://doi. org/10.24205/03276716.2020.858 513 .

7 Fajar Syarif, "The History of Madrasa Development in Indonesia," Tsaqofah \& Tarikb: Jurnal Kebudayaan Dan Sejarah Islam 5, no. 1 (2020): 23-40.

8 Ronald Lukens-Bull, "Pesantren, Madrasa and the Future of Islamic Education in Indonesia," Kawalu: Journal of Local Culture 6, no. 1 (2019): 29-48, https://doi.org/10.32678/kawalu.v6i1.2044.

9 Istikomah Istikomah, Eni Fariyatul Fahyuni, and Imam Fauji, "Integration of Schools and Madrassa into Pesantren in Indonesia," in 1st International Conference on Intellectuals' Global Responsibility (ICIGR 2017) (Advances in Social Science, Education and Humanities Research (ASSEHR), 2018), 141-43, https://doi.org/10.2991/icigr-17.2018.34.

${ }^{10}$ Muh. Takdir, "SISTEM NILAI KEARIFAN LOKAL DALAM MANAJEMEN SEKOLAH YANG BERORIENTASI BUDAYA MUTU” (UNIVERSITAS PENDIDIKAN INDONESIA, 2020). 
Therefore madrasa must rethingking marketing, strategy and innovation, dialogue with reality, change and the development of the times, madrasa will still be par of exelence and pride of Indonesian Muslims. ${ }^{11}$

Kurniawan's research focuses on the condition of madrasa in Indonesia and their development which is studied according to michael faucault's perspective on power, knowledge and discourse. This study discusses the performance of madrasa that are still relatively low and inferior to public schools or pesantren. ${ }^{12}$ Islamic education was marginalized from the Dutch colonial era to sukarno's government which produced as if Islamic education were second-class. Then since the fall of the new order in 1998, the number of madrassas has increased in various cities. ${ }^{13}$ Madrasa has not been considered important and is a top priority in the implementation of the national education system in Indonesia. ${ }^{14}$

Jazeel conducted research on Outcome-based education (OBE) in 96 Madrasa in Sri Lanka which stated that the outcome-based curricula curriculum does not yet exist in most madrasa. ${ }^{15}$

Madrasa in Banglades: Teaches skills that are inecorrable to the modern economy so as to cause unemployment and poverty, do not promote the value of citizenship in democracy, and many are still outside the state curriculum. This can trigger radicalism. ${ }^{16}$

Zaini's writing further highlights the contribution of Islamic institutions to realize indonesia's golden generation and its efforts to make it happen in the context of Islamization (Qur'an and Hadith). ${ }^{17}$

11 Imam Machali Machali, "RETHINGKING MARKETING MADRASA Menimbang Pola Dan Strategi Pemasaran Jasa Pendidikan Madrasa," EDUKASI: Jurnal Penelitian Pendidikan Agama Dan Keagamaan 13, no. 1 (2015): 1-14, https://doi.org/10.32729/edukasi.v13i1.230.

12 Syamsul Kurniawan and Muhammad Miftah, "The Madrasa in Indonesia (Auhtority, Knowledge and Discourse Surrounding Its Development)," Edukasia 15, no. 2 (2020): 231-50.

$13 \mathrm{OECD}$ and ADB, Education in Indonesia: Rising to the Challenge, Far Eastern Survey (Paris, 2015), https://doi.org/http://dx.doi.org/10.1787/9789264230750-en.

14 Badrudin Badrudin, "Indonesia’s Educational Policies on Madrasa Diniyah (MD)," Jurnal Pendidikan Islam 3, no. 1 (2017): 17-32, https://doi.org/10.15575/jpi.v3i1.850.

15 M. I. M. Jazeel, "Application of Outcome-Based Curriculum in Religious Studies: The Case of Madrasas in Sri Lanka," Journal of Politics and Law 13, no. 3 (2020): 196-202, https://doi.org/10.5539/ jpl.v13n3p196.

16 Niaz Asadullah et al., "Secondary School Madrasas in Bangladesh : Incidence, Quality, and Implications for Reform," World Bank., 2010, https://openknowledge.worldbank.org/handle/10986/18487.

17 Hasan Zaini, "ISLAMIC INSTITUTION CONTRIBUTION IN BUILDING INDONESIAN GOLDEN GENERATION," Proceeding International Seminar on Education 2016 Faculty of Tarbiyah and Teacher Training, 2016. 
Taylor's research discusses madrassas and social mobility in theeconomicreligious frame at Nadwat al-'Ulama in Lucknow. ${ }^{18}$

Abrori's research shows that public trust relationships are not always based on rational economic transactional considerations but are also based on moral rationality and religiosity. ${ }^{19}$ Abdullah's research stated that peran head of madrasa is very important in successfully maintaining the quality culture of madrasa. ${ }^{20}$ Salim's research shows that madrasa reject radicalism through social construction processes (externalization, objectification and internalization). ${ }^{21}$

\section{Literature Review}

The development of society from the industrial revolution to the information society. Masyarakat information can be seen from his ability in mastery of information technology, able to compete, curious, imaginative, able to turn challenges into opportunities, and master various methods in problem solving. This is because the problems that arise in this era of globalization become more complex and require a more varied and accommodating response. In addition, by using various information technologies to find, explore, analyze, and exchange information efficiently and effectively. ${ }^{22}$

Competition in the era of globalization is getting tighter with the open partition between countries through cyberspace. To survive such conditions, students must have competencies relevant to the demands of the globalisas era. Competitive human resources in the industry 4.0 era is not enough only with old literacy in the form of writing, reading and counting, but it needs data literacy, technology literacy and human literacy. ${ }^{23}$ Solahudin's post stated that social

18 Christopher B. Taylor, "Madrasas and Social Mobility in the Religious Economy: The Case of Nadwat Al'Ulama in Lucknow,' South Asia Multidisciplinary Academic Journal 11 (2015): 1-18, https://doi.org/10.4000/ samaj.3932.

19 M Sayyidul Abrori and Moh. Solikul Hadi, "Integral Values in Madrasa: To Foster Community Trust in Education," Istawa: Jurnal Pendidikan Islam 5, no. 2 (2020): 160-78, https://doi.org/10.24269/ijpi. v5i2.2736.

20 Mukhammad Abdullah, "School Culture to Serve Performance of Madrasa in Indonesia," QIJIS (Qudus International Journal of Islamic Studies) 7, no. 1 (2019): 71-100, https://doi.org/10.21043/qiiis.v7i1.4809.

21 Ahmad Salim, "The Madrasa Resistance Against Radicalism," Nadwa : Jurnal Pendidikan Islam 13, no. 2 (2019): 315-36, https://doi.org/10.21580/nw.2019.13.2.5173.

22 Muhammad Aji Nugroho, "Pemanfaatan Teknologi Informasi Dalam Peningkatan Mutu Pendidikan Islam Di Madrasa," MUDARRIS A: Journal of Islamic Education 6, no. 1 (2015): 3060, https://doi.org/10.18326/mdr.v6i1.758.

23 Risnita and Sohiron, "Tantangan Manajemen Pendidikan Islam, Hukum Islam Dan Bahasa Melayu Di Era Revolusi 4.0," in Studi Visit Program Pascasarjana UIN STS Jambi Tabun 2019, ed. Ahmad Husen Ritonga (Jambi: Pascasarjana UIN STS Jambi, 2019), 95-104. 
media has become a productive space for the development of religious populism in Indonesia. ${ }^{24}$

Madrasa has an important role and position for the implementation of education in an effort to print future generations of the nation. ${ }^{25}$ To build the quality culture of madrasa by developing the talents and potential of learners and optimization of learning activities. ${ }^{26}$ Therefore, madrasa are currently struggling to adjust to the rapidly growing communication technology. ${ }^{27}$ If madrasa are unable to adjust to technological developments, it will be difficult to catch up.

Politics policies determines the direction and fate of Islamic education in the country. Similarly, Islamic education gave birth to many political figures and statesmen who spread in various fields in government. ${ }^{28}$

Presence new media has an impact on the development of Islamic da'wah, especially related to the authority of da'wah. There are at least 5 influences of the new media for Islamic education, namely first, the authority of da'wah has shifted from the sending authority to the authority of the recipient who is free and active in interpreting the message of da'wah. Second, in the realm of new media there is no clear boundary between the sender and the recipient of da'wah message so that one can be the sender as well as the recipient of da'wah. Third, the new media allows the opening of interfaith dialogue space. Fourth, feedback from da'wah recipients requires that the message conveyed must be valid, argumentative, and convincing. Fifth, da'wah in new media can no longer be forced to be accepted by the recipient unless based on certain considerations from the recipient. ${ }^{29}$

Amir's research stated that to shape the quality culture of madrasa is carried out in five ways, namely designing standards of attitudes and behaviors oriented towards high performance standards, formulating the best service standards to

24 Dindin Solahudin and Moch Fakhruroji, "Internet and Islamic Learning Practices in Indonesia: Social Media, Religious Populism, and Religious Authority," Religions 11, no. 19 (2020): 1-12, https://doi. org/10.3390/rel11010019.

25 Faridah Alawiyah, "Pendidikan Madrasa Di Indonesia," Jurnal Aspirasi 5, no. 1 (2014): 51-58.

26 Zuliyanta, "Optimalisasi Budaya Mutu Madrasa Sebagai Upaya Meningkatkan Prestasi Akademik Di MI Ma’arif Sendang Kulon Progo” (UIN Sunan Kalijaga Yogyakarta, 2018).

27 R. Dedy Supriatna and Sita Ratnaningsih, "Indonesian Madrasa in the Era of Globalization," TARBIYA: Journal of Education in Muslim Society 4, no. 1 (2017): 90-103, https://doi.org/10.15408/tjems.v4i1.5908.

28 Choirul Mahfud, "RETHINKING POLITIK PENDIDIKAN ISLAM DI INDONESIA," Jurnal Madania 1, no. 2 (2011): 128-48.

29 Adeni, "ONLINE RELIGION AND RETHINKING THE DA'WAH AUTHORITY TOWARD AN INCLUSIVE DA'WAH: A CONCEPTUAL STUDY,” Jurnal Dakwah 21, no. 1 (2020): 111-35. 
students and parents, integrating quality culture in all madrasa activities, providing rewards and punishment, and providing motivation to all madrasa residents. ${ }^{30}$

Sofanudin's paper concludes that related to quality-oriented management in educational innovation there are at least 4, namely branding innovation, innovation in the acceptance of new students, curriculum innovation, and learning innovation. ${ }^{31}$

Islamic education plays an important role in building the nation, and is therefore given a special position in national education laws in Indonesia and Malaysia. Although there is still a perspective that places Islamic education as a second-class subject that is considered inferior when compared to public education subjects, this same problem gives birth to the realization that Islamic education must play an important role in one's life, so that it can be felt in every aspect of society. ${ }^{32}$

School culture stems from (1) values, norms, and behaviors; (2). the physical environment of the school: beauty, security, comfort, tranquility, and cleanliness; (3). School system: quality-based, principal leadership, discipline and order, awards and incentives, achievement expectations, access to information, evaluation, intensive and open communication. Schools with an established school culture achieve better academic and non-academic achievement. ${ }^{33}$

Therefore, dneed reflection or dialogue between different elements (Islamic and Western thought) in the process of interdisciplinary Islamic education with so as not to create a binary opposition that contradicts each other and leads to extreme actions. ${ }^{34}$

Hanun mentioned that madrasa with bilingual classes are implemented to produce the next generation of qualified and mastering foreign languages. This program is supported by cooperation with the International Cambride Institute, the role of madrasa committees and madrasa heads towards improving the quality

30 Amir, "MEMBANGUN BUDAYA MUTU PADA LEMBAGA PENDIDIKAN ISLAM MENUJU MADRASA UNGGUL," Al-Tanzim : Jurnal Manajemen Pendidikan Islam 3, no. 2 (2019): 1-12, https:// ejournal.unuja.ac.id/index.php/al-tanzim.

31 Aji Sofanudin et al., "Quality-Oriented Management of Educational Innovation at Madrasa Ibtidaiyah," Journal of Education and Practice 7, no. 27 (2016): 176-80.

32 UntungMargono, "IslamicEducationinIndonesiaandMalaysia(TheExistenceandImplementationuntil20th Century)," Jurnal At-Ta'dib 7, no. 2 (2012): 363-78.

33 Abdullah, "School Culture to Serve Performance of Madrasa in Indonesia."

34 Abdullah Sahin, "Critical Issues in Islamic Education Studies: Rethinking Islamic and Western Liberal Secular Values of Education,” Religions 9 (2018): 1-29, https://doi.org/10.3390/ rel9110335. 
of education. The disadvantages of a program with a cooperative model require a lot of time, sarpras and incomplete learning resources. ${ }^{35}$

\section{Method}

Research methods are a scientific way to obtain data with specific purposes and uses. ${ }^{36}$ This type of research is qualitative research and includes field research. Qualitative method, which is a method that uses the study of documents relevant to this research so as to produce a discourse that can benefit everyone. ${ }^{37}$ Data that researchers obtained from this study such as observations, written snippets of documents, field records compiled by researchers at the research site. In this study is not poured in statistical forms and numbers. In this study, researchers directly analyzed the data by enriching the information through comparative analysis, as long as it did not eliminate the original data. ${ }^{38}$ Data analysis using Miles and Huberman analysis techniques that include data reduction, display data, and conclusion drawing/verification. ${ }^{39}$

\section{Result and Discussion}

After conducting research in Madrasa Tsanawiyah (MTs) Ma'arif NU 4 Kemranjen author found the quality culture of madrasa in MTs Ma'arif NU 4 Kemranjen namely; mushofahah, Commemoration of Islamic Holidays (PHBI), reading asmaul busna, memorization juz 'amma, istighasah and prayer together, the use of polite uniforms and covering the aurat, dhuha prayer, friday walking boxes, congregational dhuhur prayers, islamic fasts, readings yasin and tahlil, religious extracurricular, religiousmessages, religious tests and halal bi halal.

Quality culture developed in MTs Ma'arif NU 4 Kemranjen is as follows:

A. Madrasa Quality Culture Form

1) Mushofahah

Based on the findings of research that has been carried out in

35 Farida Hanun, “OUTSTANDING MADRASA WITH BILINGUAL CLASS,” Dialog 41, no. 1 (2018): 53-63, https://doi.org/10.47655/dialog.v41i1.284.

36 Sugiono, Metode Penelitan Kuantitatif, Kualitatif Dan R\&D, Alfabeta (Bandung: Alfabeta, 2009).

37 Lexy J. Moleong, "Metodologi Penelitian Kualitatif (Edisi Revisi)," in PT. Remaja Rosda Karya (Bandung: PT Remaja Rosdakarya, 2006), 9.

38 Nana Sudjana, Penilaian Hasil Proses Belajar Mengajar, Sinar Baru Algesindo (Bandung: Sinar Baru Algesindo, 2007).

39 Matthew B Miles and A Michael Hubberman, Qualitative Data Analisys, Sage Publication (SAGE Publication, 1994). 
MTs Ma'arif NU 4 Kemranjen, mushofahah culture becomes an excellent culture in MTs Ma'arif NU 4 Kemranjen. In asmaun sahlan, mushofahah can be called 3S culture (smile, say hello, greetings). Islam teaches about greeting others by saying greetings and shaking hands when meeting. Greetings are prayers for those who are greeted with greetings and Islam requires those who hear greetings to answer them. Judging from the psychological aspect, greetings and shaking hands accompanied by smiles can strengthen the positive relationship between teachers and students. This will have an impact on the emergence of student respect for teachers.

Mushofahah is a welcoming of students in front of the madrasa gate accompanied by greetings and smiles by teachers or employees aiming to form polite individuals. Similarly, when the students had finished their study in madrasa, they shook hands kissing the teacher's hand. This is as expressed by the fiqh subject teacher, MH Usman:

"every morning when students come to Madrasa, we welcome Mushofahah, which is shaking hands with students. This activity aims to form a polite Muslim person. In addition, it is also to train the discipline and neatness of students. If there are students who are notneatly dressed,for example the clothes are not inserted, we reprimand. If we've been reprimanded many times, I usually scratch a little on his shirt with a cutter,this is so that studentsdeter. For welldressed students, we reward them, even with words like 'good, great, cool'. Similarly, when they want to go home, they also shake hands while kissing the teacher's hand." ${ }^{40}$

In mushofahah contained elements of courtesy and mutual respect. In line with this, in Islam there is the concept of ukhuwab and tawadlu' The concept of ukhuwah (brotherhood) has a strong normative foundation, many verses of the Qur'an that speak of this, mentioned in Surah al-Hujarat verse 13.

The concept of tawadlu' language is to be able to put one's self, meaning one must be able to behave and behave as well as possible (humble, respectful, polite and not arrogant). In Islam the teacher is highly respected so there is the concept of "blessing", meaning that a student will only get useful knowledge when obtaining pleasure

40 MH Usman, "Wawancara," 2015. 
from the teacher. This concept is very appropriate with the behavior of students when kissing the teacher's hand when shaking hands in mushofahah.

2) Islamic Big Day Reminder (PHBI)

This PHBI activity is always held to commemorate historical days in Islam. Although the event has long passed, but until now the event can still have a positive impact on Muslims, especially residents of MTs Ma'arif NU 4 Kemranjen.

According to the findings of the study when the author conducted an interview with Sugeng Riyadi, as a student waka, the commemoration of Isra Mi'raj was held on May 21, 2015. The activity was held to coincide with the release of grade IX students who had graduated. The activity begins with the reading of juz' amma and asmaul husna. Then displays hadroh from students who follow extra-curricular hadroh. Similarly, extra-curricular qira'ah, displays the recitation of holy verses of the Qur'an at the event. This activity involves parents/ guardians of students, nu administrators and Muslims of Alasmalang twigs, as well as residents around madrasa. ${ }^{41}$

As for the commemoration of maulid prophet, held to commemorate the birth of the noblest man, the prophet Muhammad saw. In this activity also begins with the reading of the book al-barjanzi accompanied by a group of hadroh from students. Then there is the recitation of the holy verses of the Quran. After that in the contents of the study by inviting the local kiyai. With the commemoration of the islamic big day, it is expected that the students will be able to live every major event in Islam and appreciate the struggle of the previous prophet in fighting for the teachings of Islam. In addition, it can also take wisdom or learning from every incident that occurred in the time of the prophet Mohammed so that it can be applied in daily life. ${ }^{42}$

3) Reading asmaul busna

Asmaul husna readings are carried out in the morning before the learning begins. Asmaul busna reading for grade IX is accompanied by teachers who teach at the first hour, while for grade VII and grade VIII

41 Sugeng Riyadi, “Wawancara,” 2015.

42 Riyadi. 
accompanied by grade IX students. ${ }^{43}$

Based on the findings of the study, after the sound of the bell ringing, all students entered their classes. Then they started reading asmaul busna in their respective classes. ${ }^{44}$ The Prophet informs us that God has 99 good names and whoever practices them will enter Paradise. This activity according to the head of MTs Ma'arif NU 4 Kemranjen aims to instill character in the form of religious values contained in the meaning of asmaul husna. Thus, children will be more easily directed to positive things. ${ }^{45}$ By understanding the content of asmaul husna, students will know Allah SWT better.

4) Memorization juz 'amma

Juz' Amma is the last juz in the Quran, namely juz 30. It is often referred to as juz 'amma because at the beginning of juz, that is, in the letter an-Naba' in thebeginning with the verse "amma yatasaa aluun". Based on the findings of on-site research that to make it easier for students to memorize the entire Juz 30. Actually memorizing juz 'amma is the same as learning to memorize the Qur'an.

In order not to be a heavy burden for students, the target is made every level of grades VII, VIII, and IX. The first year in grade VII is required to be able to memorize from surat an-Naas to adb-Dhuba. In the second year that is during class VIII from surat al-Lail to alBuruj. While in class IX from surah al-Insyiqaq to an-Naba'. ${ }^{46}$

Memorizing juz 'amma is a form of worship that is believed to be able to draw closer to Allah SWT. Can increase faith and piety that implies positive attitudes and behaviors, can control themselves, can be calm, oral awake, and istiqomah in worship.

Memorization juz 'amma in addition to being a form of worship, can also increase faith and love in the Qur'an, and can foster a positive attitude, therefore through tadarus al-Qur'an students can grow noble attitudes so as to influence the improvement of learning achievement and can also fortify themselves from negative cultures.

The author also held interviews with several grade VII students,

\footnotetext{
43 Riyadi.

44 “Observasi," 2015.

45 Muhamad Fatoni, "Wawancara," 2015.

46 Usman, "Wawancara."
} 
namely Riski, Udin, and Eko. When the author asked if they had memorized juz' amma or not, they replied not yet memorized. Then when meeting with a grade VIII student named Alif, he claimed to have memorized until the letter al-Buruj ${ }^{47}$ This proves that memorizing juz' amma can already improve the memorization of students.

5) Istighasah and prayer together

Istighasah and prayer together is to say prayers together with the aim of asking for help from Allah SWT. The essence of this activity is actually $d z i k r u l l a h$ in the framework of taqarub ila Allah (closer to Allah SWT). If man as a servant is always close to the Khaliq, then all his wishes will be granted by Him.

Istighasah is carried out regularly every Thursday night wage at the mushola MTs Ma'arif NU 4 Kemranjen. This activity was attended by grade IX students who will face the National Examination (UN) along with parents / guardians. Led by a kiyai, the students are taught to draw closer to Allah SWT. Thus, it is expected that students and parents alike ask Allah SWT so that it is given smoothness in every step, especially when facing the National Examination (UN). ${ }^{48}$ This is in line with what was expressed by Mrs. Siti Hartini as a teacher of Quran Hadith and Aqidah Akhlak that istighasah and prayer together aims to provide mental provision to students who will face the National Examination, in addition to providing more material through tutoring. 49

Not only that, in addition to istighasah and prayer together on Thursday night wage, before the National Examination also held a pilgrimage to the tomb of walisanga in central Java. According to information from Mr. MH Usman as a figh teacher, this activity in collaboration with NU Muslimat Alasmalang branch. ${ }^{50}$

6) Polite use of uniforms and covering the aurat

MTs Ma'arif NU 4 Kemranjen requires men to wear trousers and

\footnotetext{
Riski, Udin, and Eko, "Interview," 2015.

Fatoni, "Wawancara."

Siti Hartini, "Wawancara," 2015.

Usman, "Wawancara."
} 
wear peci when in madrasa. Likewise, female students are required to wear a veil and long and not thin clothes. This aims to get students used to covering their nakedness, both in madrasa and outside. Starting from covering the aurat, it is expected that students can keep from negative actions.

Based on the interview that the author did with the Head of MTs Ma'arif NU 4 Kemranjen, Mr. Muhamad Fathoni stated that from the madrasa provides support facilities in the form of giving free peci and veils to grade VII students every year. This aims to encourage and familiarize students to always cover their aurat. If students wear clothes that cover their nakedness, especially wearing a veil or peci it is not only as an identity for MTs students, but also as a guard against negative actions. If students wear peci or veils it would be a shame to do negative things. ${ }^{51}$

This verse is the basis for ordering Muslims to cover their aurat. Although it started with the coercion that became the rule of the school, according to Mr. Sugeng Riyadi wearing a polite uniform and covering the aurat is not only a habit in madrasa. However, most of the students make this a habit both in the madrasa environment and outside the madrasa. Thus the awareness of the students will have arisen with the habituation. Even after they graduated from MTs Ma'arif NU 4 Kemranjen, they continued to wear the hijab. ${ }^{52}$

7) Prayer dhuba

Dhuha prayer is performed during the first break in turn each class. The implementation is from Monday to Thursday according to the schedule that has been determined. This is because the capacity of the mosque that has not been able to accommodate all students so it must be carried out in turns. Dhuha prayer is a practice of sunnah taught by the Prophet Muhammad SAW. Dhuha prayer also has many fadhilah or priorities for the students. People who are accustomed to dhuha prayer, will get a smooth rizki and blessings. In addition, dhuha prayer is also an expression of gratitude to God for every joint in our body. More importantly that by praying dhuha, the sins will be forgiven

51 Fatoni, "Wawancara."

52 Riyadi, "Wawancara." 
even as much as the froth in the sea. ${ }^{53}$

8) Friday box running

Friday box running is a term used by students who become the administrator of IPNU-IPPNU MTs Ma'arif NU 4 Kemranjen. Based on the interview with the Chairman of IPNU, Syarifudin mentioned that every Friday there is a friday box running. Ipnu-IPPNU management in charge of traveling around the class brought boxes for charity. The result of the infak is used to visit if there is a friend who is sick or has a disaster. In addition, it is also used to provide compensation if there are parents of students or residents around MTs who died. ${ }^{54}$

According to Mr. Muhamad Fathoni, with this Friday box running can train students to give charity. More than that, if there are parents of students or the community who died, teachers, employees and students follow taziyah to the house of the person who got the disaster. There they prayed in congregation. So what teachers teach in madrasa is directly practiced in daily life, so it is expected that students will get used to it and not be afraid to pray the bodies. Thus, the social soul of the students will be awakened, so that when they enter the community they can adjust. ${ }^{55}$

9) Congregational dhubur prayer

The Dhuhur prayer in congregation is carried out like dhuha prayer, which is in turn because the capacity of the prayer room is not able to accommodate all students. The implementation is Monday through Thursday on the second break. According to MH Usman, that in order for the congregation to perform the dhuhur prayer to be effective, absences are given to students. ${ }^{56}$

According to Muhamad Fathoni, the habituation of congregational dhuhur prayer is useful so that students get used to praying at the beginning of time. Dhuhur prayer has become a habit for students. Doing worship by taking wudlu followed by congregational dhuhur prayer, has implications on spirituality and mentality for a person who will and is learning. In Islam a person who will study is encouraged to

\footnotetext{
Hartini, "Wawancara."

Syarifudin, "Wawancara," 2015.

Fatoni, "Wawancara."

Usman, "Wawancara."
} 
do self-purification both physically and spiritually. ${ }^{57}$

10) Flash pesantren

Pesantren lightning is a routine agenda in MTs Ma'arif NU 4 Kemranjen every Ramadan. Pesantren kilat is carried out as a means to deepen the knowledge of Islamic students. This is very important because almost all of the students of MTs Ma'arif NU 4 Kemranjen come from elementary schools (SD) that provide religious learning in a very limited time.

This lightning pesantren activity was carried out for 6 days 1 night. On the last night, it is mandatory to stay overnight to join the open, tarawih and sahur activities together. After tarawih prayer there is also a pildacil competition and watch together. ${ }^{58}$ This activity was accompanied by teachers and employees of MTs Ma'arif NU 4 Kemranjen. In addition, it also involves local residents on kultum activities, open together and zakat fitrah.

This activity starts from 07.30 to 12.00 WIB. On the first day only socialization as well as division of groups. Groups created based on the names of figures in Islam. On the second day and next the activity begins with the reading of juz 'amma and asmaul husna. Then followed by tayamum material, dhuha prayer and ended with dhuhur pilgrims. On the third day of activities after the reading of asmaul buzna and juz 'amma, followed by the practice of dhuha prayer together and fiqh material. Then on the fourth day there is tayamum practice and tajwid practice. On the last day of the activity is carried out overnight, namely on Saturday nights.

On the fifth day, the students practiced zakat, by bringing $2.5 \mathrm{~kg}$ of rice or money worth of rice. Guided by Mr. Kiyai Muslihin, students in groups practice the intention of giving zakat fitrah. While the other students waited in class while waiting to be called by the teacher in charge of carrying out the practice of zakat fitrah. ${ }^{59}$

Then based on the author's observations, participants came back to the madrasa at $17.00 \mathrm{WIB}$, they brought overnight equipment and supplies to break the fast together. At about 17.20 WIB the Head of

\footnotetext{
Usman.

"Observasi."

"Observasi."
} 
MTs Ma'arif NU 4 Kemranjen began directing students to sit in the madrasa yard that had been given a mat. The men's students sit neatly to the south while the girls are on the north side. Next to the front sits in a row Mr. Muhamad Fathoni, Mr. Kiyai Mukhlisin and some residents around MTs. Not long after, kultum while waiting for iftar started by Kyai Mukhlisin. Kultum ends when iftar time has arrived. After breaking the fast, all of them rushed to take ablution water and pray maghrib. Students of MTs Ma'arif NU 4 Kemranjen seemed very enthusiastic to participate in the activity. ${ }^{60}$

Not stopping there, the author also asked some grade VII students, namely Riski, Udin, and Eko about the lightning pesantren activities that they had participated in for 6 days. They feel happy and satisfied when they follow the flash pesantren in MTs Ma'arif NU 4 Kemranjen. This is because the activities are more interesting than in elementary school. ${ }^{61}$

With this activity is expected to be able to form the personality of more religious learners. And it can increase the faith and piety of learners. In addition, it is expected that it can be a good educational experience for students so that in the next days even though it is not the month of Ramadan can be applied properly, both in the madrasa environment and outside the school.

11) Yasin and Tablil readings

The reading of Yasin and Tahlil was held on Friday morning after the reading of asmaul husna and juz 'amma. The reading of Yasin and Tahlil is done alternately every Friday. Suppose Friday in the first week is carried out reading Yasin, eating Friday the following week carrying out tahlil readings. Reading Yasin and Tahlil is the same as reading the Quran, but has certain priorities. In essence, reading Yasin and Tahlil is used as a prayer for yourself, parents and muslims / Muslims both alive and dead. Although there are various differences of opinion on the matter, that is clearly not a problem. With this culture, it is expected that students will become accustomed to carry out the practice so that it can improve the spiritual and mental soul in order to become closer

60 "Observasi."

61 Riski, Udin, and Eko, "Wawancara." 
to Allah SWT. Thus students will grow into human beings who can build the nation and the country.

12) Religious extracurriculars

Religious extracurriculars are held on Saturday afternoons at around 11.30 to $13.00 \mathrm{WIB}$. This extra-curricular religious activity is in the form of hadroh, qira'ah, and drum bands with songs that breathe Islam. This extra-curricular was attended by all students in grade VII and grade VIII, which is about 65 students. $^{62}$

According to Mr. Muhamad Fathoni, with extra-curricular will increase the time for students to be in madrasa. This can be used as an alternative to problem solving against time constraints in madrasa. All students in grades VII and VIII are required to attend the extracurricular. They choose according to their talents and interests. This aims to train students so that they have more skills related to religious art. ${ }^{63}$

13) Religious message

Religious messages are the writing of pearl words plastered on the walls of madrasa. The word pearl is derived from the hadith or the word of the cleric who has become a proverb. Based on the observations made by the author, the writings include:

a) “" which means "no science is obtained by relaxing".

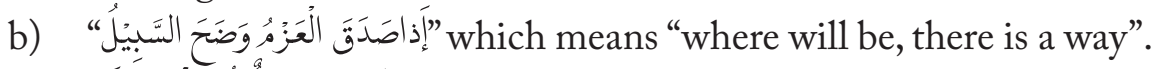

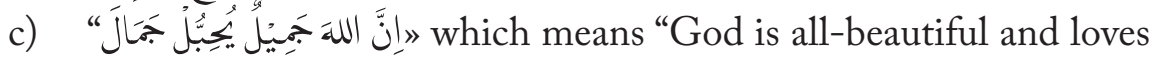
beauty".

d) "clean is beautiful, clean is healthy"

e) " means “the best sitting friend of all time is a book".

f) "I came home bringing knowledge".

g) “ِ which means “the behavior of a person shows the contents of his heart". ${ }^{64}$

Religious messages displayed on the walls of madrasa will be easy

62 Bisri Mustofa, "Wawancara," 2015.

63 Fatoni, "Wawancara."

64 "Observasi." 
to read, because it is located in a place that is easily accessible to students. The message is expected not only as a display that is without meaning, but is expected to be internalized in the personality of students then become a reference in doing activities in daily life.

14) Religious test

Religious test is a religious test that is carried out for all students of MTs Ma'arif NU 4 Kemranjen. Based on the results of the interview with Mrs. Siti Hartini, this religious test activity was carried out after the Midterm Examination (UTS) and final semester examination (UAS). This religious test is a religious test for all students after what is done during the half semester which includes memorizing the prayers and also memorizing juz 'amma. ${ }^{65}$ With this religious test, students become serious in following every quality culture of madrasa applied in MTs Ma'arif NU 4 Kemranjen.

15) Halal bi halal

Halal bi halal is a form of apology for all mistakes between human beings. Indonesia has a halal bi halal culture in the month of Shawal to visit relatives, neighbors, co-workers, friends and people he has known. This is because during hanging out with humans it is very possible to make mistakes.

MTs Ma'arif NU 4 Kemranjen implement halal bi halal at the beginning of entering madrasa. Halal bi halal in madrasa here is carried out simply, but does not lose the essence of halal bi halal itself.

\section{B. Quality Culture Strategy at MTs Ma'arif NU 4 Kemranjen}

Based on the research that the authors did, the strategy to cultivate the quality of madrasa in MTs Ma'arif NU 4 Kemranjen is more dominant through habituation and accuracy. According to Mrs. Siti Hartini, habituation is necessary karena this will be beneficial for all madrasa residents. For example, for dhuha prayer, we schedule daily for a certain class, the next day another class, because the place of ablution and musholanya has a limited capacity. In addition, it is also usual for mushofahah, asmaul husna readings, mushofahah, dhuhur pilgrims and others. ${ }^{66}$ This is also reinforced by Mr. MH Usman's statement that the strategy

65 Hartini, "Wawancara."

66 Hartini. 
used in implementing the madrasa's quality culture is through ketaladanan or giving examples to students such as taziyah and jama'ah prayer. ${ }^{67}$

In the process, madrasa heads, teachers, and employees set a good example so that students easily do what the madrasa rules. Based on the findings of the study when students were told to ta'ziyah and pray the bodies then the head of the madrasa also joined taziyah even to believe the prayer. With this approach, it will make the driving force for teachers, employees and students to get used to cultivating religious attitudes in everyday life, especially in madrasa. ${ }^{68}$

This shows that the implementation of quality culture of madrasa in madrasa is important to be implemented and to make it clear that religious education is not only the responsibility of pai teachers, but also the responsibility of all elements in madrasa, parents and communities.

Implementation of madrasa quality culture in MTs Ma'arif NU 4 Kemranjen is a series of activities carried out by all madrasa stake-holders in order to increase the religiosity of madrasa residents. To achieve this, the Head of MTs Ma'arif NU 4 Kemranjen also involved various components of madrasa to play a role in supporting various madrasa policies. These roles include:

1) Headmaster

The role of the headmaster in the implementation of madrasa quality culture in MTs Ma'arif NU 4 Kemranjen include: setting an example, monitoring the course of activities, as well as procurement of facilities and infrastructure to support the implementation of quality culture madrasa. ${ }^{69}$

2) Teacher

The role of teachers, especially religious teachers has a role in monitoring and supervising students in various religious activities and becoming religious extracurricular coaches. It also reprimands and advises students if anyone breaks the rules. Teachers also play a role to set an example for students to be religious.

3) Staff Employees

Staff and employees are also involved in the implementation of madrasa qualityculture, such as: being a examiner on religioustests, participating

\footnotetext{
Usman, "Wawancara."

68 Fatoni, "Wawancara."

69 Fatoni.
} 
in congregational dhuhur prayers, mushofahah, and Sunday morning prayers. $^{70}$

4) IPNU-IPPNU

The role of IPNU -IPPNU as an intra madrasa organization in the implementation is to be involved in the training of students who are packed in the box friday running and PHBI. ${ }^{71}$

5) Parent of Students

Parents of students play a role in various activities, including: sunday morning lectures, istitghasah and prayer together on Thursday night when going to the National Exam, watching the reading of asmaul husna and juz 'amma on the taking of raport, as well as supervising and directing students while in the family environment. ${ }^{72}$

6) Community Leaders

Community leaders play a role when there are PHBI activities, walisanga pilgrimages and zakat practices. Community leaders here include religious oranization figures, especially Nahdlatul Ulama.

7) Surrounding Communities

The involvement of the surrounding community contributes to the implementation of madrasa quality culture, among others: following the open together, involved in PHBI and participating in supervising students while in the community.

8) Nahdlatul Ulama

The involvement of Nahdlatul Ulama, namely as a foundation organization that houses MTs Ma'arif NU 4 Kemranjen in the form of an outpouring of thought and material to support various religious activities.

In essence, through various approaches and strategies used by MTs Ma'arif NU 4 Kemranjen in the implementation of quality culture madrasa can be conveyed the content of wills (religious values to be cultivated) to the school residents with fine words, accuracy, habituation, advice, constant necessity and not bored so that the concerned are willing to do these religious values.

\footnotetext{
Mukhakamah, "Wawancara," 2015.

Syarifudin, "Wawancara."

Fatoni, "Wawancara."
} 
C. Data Analysis of Madrasa Quality Culture Implementation in MTs Maarif NU 4 Kemranjen

Based on the findings of the study that the authors conducted in MTs Ma'arif NU 4 Kemranjen through observation, interview, and documentation, then the author will conduct data analysis to describe more about the results of the study. This analysis answers the formulation of problems in the research, namely how the implementation of quality culture madrasa in MTs Ma'arif NU 4 Kemranjen.

Melihat from the theory presented with koentjaraningrat listedin the book "Anthropology" mentions the form of culture includes three states, namely the level of value or ideas in the anut, the level of practice, and the level of cultural symbols.

At the level of values adopted, the madrasa formulated the agreed values in realizing the quality culture of madrasa in MTs Ma'arif NU 4 Kemranjen namely 15 cultures agreed as stated above. Furthermore, a good commitment and loyalty is built between all madrasa residents, especially students, through speeches during ceremonies and when learning morals, qur'an hadith, fiqh, SKI in particular or mapel general. Through learning in the classroom is conveyed the values that want to be realized in religious activities that are commendable as a culture in MTs Ma'arif NU 4 Kemranjen. These values include values related to fellow beings such as Friday boxes running to foster a social soul, as well as those related to Allah SWT such as istighasah and prayer together.

In the level of daily practice, attitude and daily behavior by all residents of MTs Ma'arif NU 4 Kemranjen as a form of quality culture madrasa. The development process can be done through three stages, namely: (1) socializing moral values as the ideal attitude and behavior to be achieved, this is done in classroom learning, speech during ceremonies and face to face with students; (2) determination of weekly or monthly action plans as stages and systematic steps that will be carried out by school residents in realizing the agreed religious values. This is done by arranging a work program by the head of madrasa, waka student, PAI teacher or IPNU-IPPNU administrator related to the technical implementation in order to be systematic.

At the level of cultural symbols, it is done by changing symbols or customs that are not in line with religious teachings and values with religious cultural symbols. In this case it can be seen from something visible to the eye. In MTs Ma'arif NU 4 Kemranjen is required to dress modestly and cover the aurat of 
both madrasa heads, teachers, staff / employees, and students. In addition, there is also a culture of religious messages in the form of pearl words affixed to the walls of madrasa. In addition to religious messages there are also pictures of clerics, calligraphy, and greetings written above the entrance. From the side of the building can be seen the color of the building paint is identical to the green color, which symbolizes that this madrasa is under the auspices of Nahdlatul Ulama. Mushala which is shaped like a javanese traditional house is in the form of "joglo". This cultural form in the form of artifacts symbolizes that madrasa teach religion while maintaining local wisdom. This makes the religious atmosphere more felt in MTs Ma'arif NU 4 Kemranjen.

In Asmaun Sahlan's theory in the book "Realizing Religious Culture in Schools" that the real purpose of religious education (Islam)is pe religion andeducation itself, not just understanding of religion. In other words, the aspects emphasized are not only on knowing aspects (knowing about religious teachings and values) and do-ing (can practice what is known) only, but rather on be-ing (religion or living life on the basis of teachings and values).

The quality culture of madrasa in this context means the cultivation of Islamic religious values followed by all madrasa citizens with the aim of instilling islamic valuesto students throughthe learning process in madrasa. This is done so that these values become an integral part of student behavior in madrasa environment and in daily life. The implementation of the quality culture of madrasa is a development of pai learning family in madrasa so that the objectives of national education or islamic education objectives of madrasa can be achieved.

Based on the results of the research that has been done in MTs Ma'arif NU 4 Kemranjen that the quality culture of madrasa is not only carried out by students, but by all components in madrasa. As mentioned in chapter III, the subjects of this study were the head of madrasa, waka student, teacher, staff and employees as well as students of MTs Ma'arif NU 4 Kemranjen.

According to Head of MTs Ma'arif NU 4 Kemranjen Mr. Muhamad Fathoni mentioned that activities related to religious culture are implemented on the basis of mutual agreement with teachers andstaff employees. The quality cultural form of this madrasa there are 15 namely (1) mushofahah (2) PHBI (3) asmaul husna (4) memorization juz 'amma (5) istighasah and prayer together (6) the use of polite uniforms and covering the aurat (7) prayer 1dhuha (8) friday box running (9) congregational dhuhur prayer (10) pesantren kilat (11) reading yasin 
and tahlil (12) extra-curricular religious (13) religious messages (14) religious tests (15) halal bi halal.

Meanwhile, according to the theory of Asmaun Sahlan in his book entitled "Realizing Religious Culture in Schools, Development of PAI from Theory toAction" mentions that the form of religious culture as mentioned in chapter II, which includes (1) smiles, greetings, greetings (3S) (2) mutual respect and tolerance (3) fasting Monday Thursday (4) dhuha prayer (5) tadarus al-Quran (6) istighasah and prayer together.

Meanwhile, according to Jamal Ma'mur Asmani's theory in his book "Manualon Internalization of Character Education in Schools" about some effective activities to be used as a culture in schools, namely (1) liven up congregational prayers (2) kiss the hands of teachers (3) make short messages in strategic places (4) hold prayers and routine istghasah (5) instill sincerity.

If juxtaposed with the two theories above, then the form of madrasa quality culture implemented in MTs Ma'arif NU 4 Kemranjen there is not yet applied, namely fasting culture on Thursday. The culture of smiles, greetings, greetings (3S), mutual respect and tolerance, and kissing the teacher's hands are realized through mushofahah culture that is carried out every morning and afternoon. While tadarus al-Quran is manifested in the form of memorization juz 'amma before learning begins. The installation of short messages in a strategic place is realized by the religious message on the walls of madrasa. Instilling sincerity is embodied with Friday's box culture walk.

The author's findings on the implementation of madrasa quality culture that has not been contained in the theory include Islamic Holidays (PHBI), readings asmaul husna, the use of polite uniforms andcovering the aurat, pesantren kilat, yasin and tahlil, religious extracurricular, religious tests, and halal bi halal.

Thus, of the 15 forms of madrasa quality culture implemented in MTs Ma'arif NU 4 Kemranjen, 7 of them are in accordance with the theory of Asmaun Sahlan and Jamal Ma'mur Asmani. While the other 8 are not contained in the theory. The form of madrasa quality culture in the form of fasting on Thursday in asmaun sahlan theory is not implemented in MTs Ma'arif NU 4 Kemranjen.

According to Muhaimin's theory, the strategy in cultivatingreligiousvalues in schools can be donethrough: (1) power strategy, namely the strategy of cultivating religion in schools by using power or through people's power (2) persuasive strategy, whichis carried out through the formation of opinions and views of the community 
or citizens of theschool; and (3) normative re-education to instill and replace the paradigm of thinking of the old school community with a new one.

In implementing the quality culture of madrasa, MTs Ma'arif NU 4 Kemranjen is more dominant in implementing persuasive strategies, namely the provision of accuracy and habituation for students. In addition, the madrasa also does not emphasize the provision of punishment for those who violate or reward the madrasa residents. Through this strategy, it is expected that students can feel well through the provision of examples and various musings to raise awareness of the importance of good behavior, namely in accordance with the values of Islamic teachings. Thus, there will appear awareness to implement the quality culture of madrasa.

\section{Conclussion}

Based on the results of research conducted by the author on the implementation of quality culture madrasa in MTs Ma'arif NU 4 Kemranjen can be concluded that wujud from the quality culture madrasa (religious culture) in MTs Ma'arif NU 4 Kemranjen as a form of development of pai subject family in accordance with the theory that includes; (1) mushofahah (2) memorization juz 'amma (3) istighasah and prayer together (4) dhuha prayer (5) friday box running (6) congregational dhuhur prayer (7) religious message. While what is not contained in the theory is (1) PHBI (2) reading asmaul husna (3) the use of polite uniforms and covering the aurat (4) pesantren kilat (5) reading yasin and tahlil (6) extra-curricular religious (7) religious tests (8) halal bihalal. The implementation uses a persuasive strategy that emphasizes on accuracy and habituation.

The task is actually not only the responsibility of the teachers of the religious teacher only, but all madrasa residents such as general mapel teachers, staff and employees, parents / guardians, and also most importantly the head of the madrasa who determines the culture of the madrasa.

\section{Acknowledgement}

Thank you to Professor Abdul Basit who has guided the writing of this journal. 


\section{Reference}

Abdullah, Mukhammad. "School Culture to Serve Performance of Madrasa in Indonesia." QIJIS (Qudus International Journal of Islamic Studies) 7, no. 1 (2019): 71-100. https://doi.org/10.21043/qiijis.v7i1.4809.

Abrori, M Sayyidul, and Moh. Solikul Hadi. "Integral Values in Madrasa: To Foster Community Trust in Education." Istawa : Jurnal Pendidikan Islam 5, no. 2 (2020): 160-78. https://doi.org/10.24269/ijpi.v5i2.2736.

Abu Bakar, Mukhlis. Rethinking Madrasa Education in a Globalised World. Edited by Mukhlis Abu Bakar. Retbinking Madrasa Education in a Globalised World. 1st ed. New York,: Routledge, 2018. https://doi.org/10.4324/9781315184234.

Adeni. "ONLINE RELIGION AND RETHINKING THE DA'WAH AUTHORITY TOWARD AN INCLUSIVE DA'WAH: A CONCEPTUAL STUDY." Jurnal Dakwah 21, no. 1 (2020): 111-35.

Aji Sofanudin, Fathur Rokhman, Wasino, and Rusdarti. "Quality-Oriented Management of Educational Innovation at Madrasa Ibtidaiyah." Journal of Education and Practice 7, no. 27 (2016): 176-80.

Alawiyah, Faridah. "Pendidikan Madrasa Di Indonesia." Jurnal Aspirasi 5, no. 1 (2014): 51-58.

Amir. "MEMBANGUN BUDAYA MUTU PADA LEMBAGA PENDIDIKAN ISLAM MENUJU MADRASA UNGGUL." Al-Tanæim : Jurnal Manajemen Pendidikan Islam 3, no. 2 (2019): 1-12. https://ejournal.unuja.ac.id/index. php/al-tanzim.

Asadullah, Niaz, Al Zayed, Syed Rashed, and Nazmul Chaudhury. "Secondary School Madrasas in Bangladesh : Incidence, Quality, and Implications for Reform." World Bank., 2010. https://openknowledge.worldbank.org/ handle/10986/18487.

Badrudin, Badrudin. "Indonesia's Educational Policies on Madrasa Diniyah (MD)." Jurnal Pendidikan Islam 3, no. 1 (2017): 17-32. https://doi.org/10.15575/jpi. v3i1.850.

Bruinessen, Martin van. "Traditionalist and Islamist Pesantrens in Contemporary Indonesia." In The Madrasa in Asia, edited by Annelies Moors, Mathijs Pelkmans, and Abdulkader Tayob, 222. Amsterdam: Amsterdam University Press, 2008. https://doi.org/10.1017/9789048501380.009. 
Fatoni, Muhamad. “Wawancara,” 2015.

Hanun, Farida. "OUTSTANDING MADRASA WITH BILINGUAL CLASS." Dialog 41, no. 1 (2018): 53-63. https://doi.org/10.47655/dialog.v41i1.284.

Hartini, Siti. "Wawancara," 2015.

Hasan, Noorhaidi. "The Salafi Madrasas of Indonesia Chapter Author(s): Noorhaidi Hasan Book Title: The Madrasa in Asia Book Subtitle: Political Activism and Transnational Linkages." In The Madrasa in Asia: Political Activism and Transnational Linkages, edited by Annelies Moors, Mathijs Pelkmans, and Abdulkader Tayob, 247. Amsterdam: Amsterdam University Press, 2008.

Istikomah, Istikomah, Eni Fariyatul Fahyuni, and Imam Fauji. "Integration of Schools and Madrassa into Pesantren in Indonesia." In 1st International Conference on Intellectuals' Global Responsibility (ICIGR 2017), 141-43. Advances in Social Science, Education and Humanities Research (ASSEHR), 2018. https://doi.org/10.2991/icigr-17.2018.34.

Jazeel, M. I. M. "Application of Outcome-Based Curriculum in Religious Studies: The Case of Madrasas in Sri Lanka." Journal of Politics and Law 13, no. 3 (2020): 196-202. https://doi.org/10.5539/jpl.v13n3p196.

Kurniawan, Syamsul, and Muhammad Miftah. "The Madrasa in Indonesia (Auhtority, Knowledge and Discourse Surrounding Its Development)." Edukasia 15, no. 2 (2020): 231-50.

Lukens-Bull, Ronald. "Pesantren, Madrasa and the Future of Islamic Education in Indonesia." Kawalu: Journal of Local Culture 6, no. 1 (2019): 29-48. https:// doi.org/10.32678/kawalu.v6i1.2044.

Machali, Imam Machali. "RETHINGKING MARKETING MADRASA Menimbang Pola Dan Strategi Pemasaran Jasa Pendidikan Madrasa." EDUKASI: Jurnal Penelitian Pendidikan Agama Dan Keagamaan 13, no. 1 (2015): 1-14. https://doi.org/10.32729/edukasi.v13i1.230.

Mahfud, Choirul. "RETHINKING POLITIK PENDIDIKAN ISLAM DI INDONESIA." Jurnal Madania 1, no. 2 (2011): 128-48.

Margono, Untung. "Islamic Education in Indonesia and Malaysia (TheExistenceandImplementationuntil20th Century)." Jurnal At-Ta'dib 7, no. 2 (2012): 363-78.

Miles, Matthew B, and A Michael Hubberman. Qualitative Data Analisys. Sage Publication. SAGE Publication, 1994. 
Moleong, Lexy J. "Metodologi Penelitian Kualitatif (Edisi Revisi)." In PT. Remaja Rosda Karya, 9. Bandung: PT Remaja Rosdakarya, 2006.

Mukhakamah. "Wawancara," 2015.

Mustofa, Bisri. "Wawancara," 2015.

Nugroho, Muhammad Aji. "Pemanfaatan Teknologi Informasi Dalam Peningkatan Mutu Pendidikan Islam Di Madrasa." MUDARRIS A: Journal of Islamic Education 6, no. 1 (2015): 30-60. https://doi.org/10.18326/mdr. v6i1.758.

"Observasi," 2015.

OECD, and ADB. Education in Indonesia: Rising to the Challenge. Far Eastern Survey. Paris, 2015. https://doi.org/http://dx.doi.org/10.1787/9789264230750en.

Republik, Kementerian Agama. "REKAPITULASI DATA POKOK PENDIDIKAN ISLAM.” EMIS, 2021. http:/ / emispendis.kemenag.go.id/ dashboard/.

Riski, Udin, and Eko. "Wawancara," 2015.

Risnita, and Sohiron. "Tantangan Manajemen Pendidikan Islam, Hukum Islam Dan Bahasa Melayu Di Era Revolusi 4.0." In Studi Visit Program Pascasarjana UIN STS Jambi Tabun 2019, edited by Ahmad Husen Ritonga, 95-104. Jambi: Pascasarjana UIN STS Jambi, 2019.

Riyadi, Sugeng. "Wawancara," 2015.

Sahin, Abdullah. "Critical Issues in Islamic Education Studies: Rethinking Islamic and Western Liberal Secular Values of Education.” Religions 9 (2018): 1-29. https://doi.org/10.3390/rel9110335.

Salim, Ahmad. "The Madrasa Resistance Against Radicalism." Nadwa: Jurnal Pendidikan Islam 13, no. 2 (2019): 315-36. https://doi.org/10.21580/ nw.2019.13.2.5173.

Solahudin, Dindin, and Moch Fakhruroji. "Internet and Islamic Learning Practices in Indonesia: Social Media, Religious Populism, and Religious Authority." Religions 11, no. 19 (2020): 1-12. https://doi.org/10.3390/rel11010019.

Sudjana, Nana. Penilaian Hasil Proses Belajar Mengajar. Sinar Baru Algesindo. Bandung: Sinar Baru Algesindo, 2007.

Sugiono. Metode Penelitan Kuantitatif, Kualitatif Dan R\&D. Alfabeta. Bandung: Alfabeta, 2009. 
Supani, Supani. "Sejarah Perkembangan Madrasa Di Indonesia." INSANLA: Jurnal Pemikiran Alternatif Kependidikan 14, no. 3 (2009): 1-14. https://doi. org/10.24090/insania.v14i3.376.

Supriatna, R. Dedy, and Sita Ratnaningsih. "Indonesian Madrasa in the Era of Globalization." TARBIYA: Journal of Education in Muslim Society 4, no. 1 (2017): 90-103. https://doi.org/10.15408/tjems.v4i1.5908.

Syar'i, Ahmad, A. Akrim, and Hamdanah. "The Development of Madrasa Education in Indonesia." Revista Argentina de Clínica Psicológica XXIX, no. 4 (2020): 513-23. https://doi.org/10.24205/03276716.2020.858 513.

Syarif, Fajar. "The History of Madrasa Development in Indonesia." Tsaqofah \& Tarikh: Jurnal Kebudayaan Dan Sejarah Islam 5, no. 1 (2020): 23-40.

Syarifudin. "Wawancara," 2015.

Takdir, Muh. "SISTEM NILAI KEARIFAN LOKAL DALAM MANAJEMEN SEKOLAH YANG BERORIENTASI BUDAYA MUTU.” UNIVERSITAS PENDIDIKAN INDONESIA, 2020.

Taylor, Christopher B. "Madrasas and Social Mobility in the Religious Economy: The Case of Nadwat Al-'Ulama in Lucknow." South Asia Multidisciplinary Academic Journal 11 (2015): 1-18. https://doi.org/10.4000/samaj.3932.

Usman, MH. "Wawancara," 2015.

Zaini, Hasan. "ISLAMIC INSTITUTION CONTRIBUTION IN BUILDING INDONESIAN GOLDEN GENERATION." Proceeding International Seminar on Education 2016 Faculty of Tarbiyah and Teacher Training, 2016.

Zuliyanta. "Optimalisasi Budaya Mutu Madrasa Sebagai Upaya Meningkatkan Prestasi Akademik Di MI Ma’arif Sendang Kulon Progo." UIN Sunan Kalijaga Yogyakarta, 2018. 